\title{
Picture Storybooks in Teaching Chinese as a Second Language
}

\author{
Elizabeth K.Y. Loh \\ University of Hong Kong
}

Follow this and additional works at: https://docs.lib.purdue.edu/clcweb

Part of the Education Commons, and the Reading and Language Commons

Dedicated to the dissemination of scholarly and professional information, Purdue University Press selects, develops, and distributes quality resources in several key subject areas for which its parent university is famous, including business, technology, health, veterinary medicine, and other selected disciplines in the humanities and sciences.

CLCWeb: Comparative Literature and Culture, the peer-reviewed, full-text, and open-access learned journal in the humanities and social sciences, publishes new scholarship following tenets of the discipline of comparative literature and the field of cultural studies designated as "comparative cultural studies." Publications in the journal are indexed in the Annual Bibliography of English Language and Literature (Chadwyck-Healey), the Arts and Humanities Citation Index (Thomson Reuters ISI), the Humanities Index (Wilson), Humanities International Complete (EBSCO), the International Bibliography of the Modern Language Association of America, and Scopus (Elsevier). The journal is affiliated with the Purdue University Press monograph series of Books in Comparative Cultural Studies. Contact: <clcweb@purdue.edu>

\section{Recommended Citation}

Loh, Elizabeth K.Y.. "Picture Storybooks in Teaching Chinese as a Second Language." CLCWeb: Comparative Literature and Culture 18.2 (2016): <https://doi.org/10.7771/1481-4374.2856>

This text has been double-blind peer reviewed by $2+1$ experts in the field.

The above text, published by Purdue University Press @Purdue University, has been downloaded 355 times as of $11 /$ $07 / 19$.

This document has been made available through Purdue e-Pubs, a service of the Purdue University Libraries. Please contact epubs@purdue.edu for additional information.

This is an Open Access journal. This means that it uses a funding model that does not charge readers or their institutions for access. Readers may freely read, download, copy, distribute, print, search, or link to the full texts of articles. This journal is covered under the CC BY-NC-ND license. 


\section{PURDUE}

UNIVERSITY PRESS <http://www.thepress.purdue.edu>

\section{CLCWeb: Comparative Literature and Culture}

ISSN 1481-4374 <http://docs.lib.purdue.edu/clcweb> Purdue University Press (CPurdue University

CLCWeb: Comparative Literature and Culture, the peer-reviewed, full-text, and open-access learned journal in the humanities and social sciences, publishes new scholarship following tenets of the discipline of comparative literature and the field of cultural studies designated as "comparative cultural studies." In addition to the publication of articles, the journal publishes review articles of scholarly books and publishes research material in its Library Series. Publications in the journal are indexed in the Annual Bibliography of English Language and Literature (ChadwyckHealey), the Arts and Humanities Citation Index (Thomson Reuters ISI), the Humanities Index (Wilson), Humanities International Complete (EBSCO), the International Bibliography of the Modern Language Association of America, and Scopus (Elsevier). The journal is affiliated with the Purdue University Press monograph series of Books in Comparative Cultural Studies. Contact: <clcweb@purdue.edu>

\section{Volume 18 Issue 2 (June 2016) Article 12 Elizabeth K.Y. Loh, "Picture Storybooks in Teaching Chinese as a Second Language" <http://docs.lib.purdue.edu/clcweb/vol18/iss2/12>}

Contents of CLCWeb: Comparative Literature and Culture 18.2 (2016) Thematic Issue New Work in the Empirical Study of Literature. Ed. Aldo Nemesio <http://docs.lib.purdue.edu/clcweb/vol18/iss2/>

Abstract: In her article "Picture Storybooks in Teaching Chinese as a Second Language" Elizabeth K.Y. Loh presents a case study of the use of picture storybooks written and illustrated by ethnic minority students who participated in a government-sponsored Chinese as a Second Language project. The oneyear teaching experiment suggests that picture storybooks as teaching materials played a significant role in enhancing students' motivation in learning Chinese. The research project resulted in students' proficiency in Chinese as a second language particularly in reading and writing. 


\section{Elizabeth K.Y. LOH}

\section{Picture Storybooks in Teaching Chinese as a Second Language}

In recent decades, there has been much debate on whether the use of picture storybooks, often considered as literary works for children, can serve as effective teaching materials in second language teaching. While the use of picture storybooks has been promoted at kindergarten and primary levels in the Sinophone world (see Cheung; Lee), the effectiveness of this format covering multiple literary genres as teaching materials for Chinese as a Second Language (CSL) for adolescent learners is yet to be explored. This is despite the fact that numerous studies on English as a Second/Foreign Language (ESL/EFL) report positive results (see, e.g., Malu). Jeffrey Arnett argues that the use of media among adolescents results in self-socialization, which differs from other socializing agents (e.g., family, afterschool care, etc.) in that they offer more choices to learners and hence give them better control over media consumption according to their own preferences and personalities (520). To a certain extent this echoes Stephen Krashen's studies on free voluntary reading in which he claims that the process may lead to compelling comprehensible input while enabling effortless and accelerated language learning. In light of this, picture storybooks are means which offer adolescent second language (L2) learners understandable language input in less demanding learning environments. The major concern, nevertheless, lies in the possible mismatch between the target audience and actual users in terms of mental age, life experiences, and language level.

Many picture storybooks in Chinese are dominated by culture-specific themes and topics, as they are targeted L1 (first language) readers while using vocabulary and sentence structures much more sophisticated than what L2 learners can usually manage. L2 learners of the Chinese language in Hong Kong are from diverse backgrounds or emerging cultures of hybridity as a result of global diasporas. These and other factors leave learners with "a mismatch between the realities of urban multilingualism and the education classification of students' language identities and backgrounds" (see Leung, Harris, Rampton 553). School language curricula often neglect these students' life experiences as well as their multiple language and ethnic identities as members of the host society with. Given that there are few picture storybooks on the market that fulfil the selection criteria of being linguistically accessible while matching adolescent L2 learners' mental age, peer-written picture storybooks serve as an alternative teaching material. Peer-written picture storybooks, written and illustrated by adolescent L2 learners for their classmates have a number of advantages over children's picture storybooks as they 1) match students' mental age and life experiences 2) are shorter in length than illustrated works for adults 3) have manageable levels of difficulty in terms of language and content, with profound implications and space for teacher-student discussions and 4) provide compelling comprehensible input.

My exploratory study, based on a university-school support project for ethnic minority (EM) learners of CSL in Hong Kong, was carried out to investigate the effectiveness of peer-written picture storybooks as teaching materials through pre-test/post-test assessment and intervention. A special program in which EM secondary students created their own picture storybooks with guidance from language education experts was launched in the academic year 2010-11 as part of a preparatory school for university project in Hong Kong. The outcome was a compilation of 22 illustrated stories in the form of a published anthology, Journey of Reading and Creation: Ethnic Minority Students and Picture Books, including "Ying Mei's Grandmother" co-authored by Kaur Kulwinder and Gobindram Kiran (see Ki and Poon 228-45) which was adopted as the course text for the subsequent intervention. This story was later published in a separate, single volume edition for distribution in the project's partnership schools. For the production of these peer-written picture storybooks, students worked in teams of two to write and illustrate the stories. They were encouraged to create stories based on their own life experiences and insights, using their own language and preferred drawing styles. Instructors from the university later proofread their creative works and offered suggestions on how to further improve the stories.

The intervention part of this study was carried out in the academic year 2012-13. EM students participating in this study came from a former "designated school" for boys (i.e., local English-language middle schools for EM students) in the New Territories, a part of Hong Kong. Via convenience sampling, 13 male research subjects were recruited for the study, namely 3 ethnically Indian students and 10 ethnically Pakistani students. Their average age was 14.1 (between 12 to 17 years old) and they had resided in Hong Kong for 11 years on average (between 2 to 14 years) with diverse sociolinguistic backgrounds. The average number of years they had been learning Chinese was 8.5. These students were able to understand and speak Cantonese with a certain level of character recognition ability. They were also able to comprehend short Chinese texts and write extremely simple Chinese compositions, yet they tended to forget the words easily and were in need of systematic development of character recognition, as well as reading and writing abilities.

Action research and quasi-experimental design were employed as major methodologies for this study. The school-based CSL curriculum used a peer-written picture storybook as the course text with theorybased input, that is, input based on the Integrative Perceptual Approach for Chinese Character Learning (see Tse, Marton, Ki, Loh 1), variation theory, systemic functional grammar, various reading theories, and drama in education. The entire project was evaluated after a one-year intervention with a pretest/post-test assessment. Through a series of strategically designed classroom activities we applied the principles of the Integrative Perceptual Approach for Teaching Chinese Characters which in turn is based on variation theory and we focused on the discernment of different parts (components of characters, including radicals) of Chinese characters in relation to whole characters. The research instruments adopted in the pre-tests and post-tests were devised for CSL learners for assessing their listening, speaking, character recognition, as well as reading and writing abilities from Shek Kam Tse's and Elizabeth Loh's 2011 Chinese Language Assessment Tool for Non-Chinese Speaking Students. The teacher 
facilitating the intervention had twenty years of teaching experience including one year in CSL teaching. Before the launch of the project, I provided the teacher with training and set the teaching objectives together with the teacher. Further, I made suggestions for the design of teaching materials and worksheets followed by lesson preparation. The teacher conducted a trial run with an after-class sharing session.

There is an increasing number of EM students (officially classified as "Non-Chinese Speaking Students" or "NCS Students") in mainstream secondary schools (usually referred to as "local schools") in Hong Kong who are learning Chinese as their second language (L2). Most of them are of East Indian or Pakistani descent, while there is also a significant percentage of Nepalese and Filipino students. In 2014, the number of EM students reached 15,600 (see Lam 1) and it has had a big impact on Chinese language education in local secondary schools. EM parents who failed to secure spots for their children in international schools or could not afford the relatively high tuition fees tend to rely on the Secondary School Places Allocation (SSPA) System through which their children will be allocated to various mainstream secondary schools (hereinafter referred to as "local schools") in the hope that their children can learn Chinese and stay in Hong Kong for study or career in the future (see Shum, Tsung, Ki 281). With the abolishment of designated schools since the academic year 2013-14, many local schools which admit only Chinese-speaking students have taken the initiative to admit EM students. The Hong Kong Secondary Chinese Language Curriculum established by the Hong Kong Curriculum Development Council (HKCDC) in 2002 formulated the Chinese language proficiency requirements for local school students and offered a Supplementary Guide in 2008 with reference to CSL teaching for EM students. Given the differences in students' CSL proficiency, CSL teaching and learning remains a complicated issue for local schools as the existing extra resources and guidelines might not be sufficient to overcome the students' challenges. Among KLA students not only key aspects of the Chinese language (namely reading, writing, listening, and speaking) pose learning difficulties, but also other requirements in the literature classroom where students read texts in classical Chinese, as well as Chinese culture classes and independent language learning demand high language proficiency, relevant cultural knowledge, and higher-order thinking.

The causes of these pedagogical challenges are related to the diverse student population and the lack of teacher training in CSL. Whereas some EM students were born in Hong Kong and started learning Chinese since kindergarten, others are (im)migrants without prior knowledge of the Chinese language. Although inter-class or cross-grade streaming based on the students' Chinese proficiency is a common practice in mainstream secondary schools, students from every group still show significant differences among themselves due to their varied sociolinguistic backgrounds. This brings overwhelming challenges for the teachers, who are often only trained to teach Chinese to L1 students. Because EM students differ across schools and across individuals in terms of their life experiences and their Chinese language proficiency, there is no single set of teaching materials that satisfies the learning needs of everyone. Therefore, teachers would have to develop their own curricula and teaching materials. What complicates this situation even more is the different learning trajectories: students from the same level or group can differ a lot from their fellow counterparts in the previous year, which means existing materials have to be revised and customized for the new cohorts of students.

Past research points out that the sequence of learning CSL should begin with listening and speaking, then lead to recognizing and writing Chinese characters, and conclude with Chinese reading and writing (see Loh and Tse 171). On average, newly-arrived EM students are usually able to master basic classroom expressions and words of place within three months with systematic training, and about 100 Chinese characters within one academic year with the help of adequate character learning strategies (see Tse and Li 208-10). However, during the process of learning Chinese, the biggest challenges faced by EM students is moving on from character recognition to Chinese reading and writing. Most EM students are native speakers of alphabetic languages and they lack orthographic knowledge of components and structures, which is fundamental yet essential for the acquisition of the ideographic Chinese script. Kwan proposed solutions to seven common problems with teaching and learning CSL in Hong Kong, include 1) language immersion, for resolving the issue of heavily code-mixed classroom discourses 2 ) comprehensible input, for resolving the issue of overly fast speaking rates of CSL teachers and 3) scaffolding to avoid overly complicated class activities. Storybook reading, especially shared storybook reading, has been reported to be an effective way of arousing alphabet knowledge (Justice and Kaderavek 137) and print awareness (Purcell-Gates, L'Allier, Smith 572-73) at early stages of literacy development among socially-marginalized children, which aligns with Kwan's findings. Given the logosyllabic and discursive nature of the Chinese language, my assumption is that the concept of alphabet knowledge and print awareness might as well be translated into character recognition and genre awareness. Past research also reveals that learning activities with picture storybooks play a key role in developing children's understanding in both oral and written language, which eventually enables them to create their own storybooks as they learn the functions and structures of characters (see Pine and Yu 98).

Understanding in differences between oral and written language is particularly relevant to the case of CSL teaching for EM students as the learners tend to mix up the spoken form (Cantonese, a regional variant of the Chinese language commonly used as a medium of instruction in Hong Kong CSL classrooms) and the written form (the Mandarin-based traditional Chinese script) in both school and everyday settings. With the acquisition of the basic units of Chinese, such as characters and short phrases through stories in the form of compelling comprehensive input, the students' decoding and reading ability gradually improves as they move on to sentence-level and genre comprehension of Chinese texts. This, in turn, prepares them to rewrite and create stories of their own for the potential enjoyment by their EM peers. Ference Marton and Shirley Booth stress with their variation theory that learning experiences can help learners to discern the invariant and variant aspects of any subject matter, which helps the students locate critical features for generalization (Learning and Awareness 145). This theory can be applied to 
character learning in that teaching materials, learning activities, and worksheets are specially designed for illustrating the relationship between components and word clusters. The theory also has implications for facilitating students' understanding of the concept of shared components and meanings in Chinese. Variation theory was also applicable to character learning during the teaching experiments, so as to help students to understand the fact that phrases sharing the same characters are often related in meaning. This is to raise EM CSL learners' awareness that words containing the component "heart" are related to emotions or feelings, which serves well to consolidate and extend the students' semantic network. Using this strategy, the students are able to guess the meanings of the words they were not familiar with. All the mentioned teaching activities aimed to build up EM students' ability to recognize Chinese characters. The automatization of decoding (i.e. character recognition) is a key prerequisite for the development of reading ability (see Leong, Tse, Loh, Ki 237-38). My study was also an attempt to evaluate the use of variation theory in the teaching of writing. While the $4 \mathrm{~W}$ (i.e., "When, Who, Where, and What") structures are invariant, the given choices in the language task provided discernment of variant combinations and space of learning for students. That said, the task was designed to build up students' sentence writing ability and the foundation for narrative writing. Further, the story genre finds its theoretical roots in functional linguistics. Michael Halliday and Christian Matthiessen point out that texts with similar meaning and function form genres (36), which, according to Suzanne Eggins, share similar structures and features (56). It is a highly practical pedagogy that allows objective analyses of texts, while encouraging students to explore the main textual features and honing their reading and writing abilities at the same time. Given the fact that the students involved in this study were vastly different in terms of their reading and writing abilities, the teacher adopted the concept of differentiation (see Tomlinson 4549; Tse, "Teaching" 22-30) by giving easier exercises with additional hints to lower-level students, while asking higher-level students to sort out the plot themselves and find out the essential elements before identifying the overall structure of the story. The objective was to enhance the students' understanding of the texts and their ability to relate sample texts to life experiences for generating personal meanings, with the ultimate goal of enhancing their reading comprehension skills.

A number of scholarly studies point out that good readers should be able to construct mental representations and hence situational models for the facilitation of comprehension (see, e.g., Bestgen and Dupont 216-17; Johnson-Laird 126; Noordman and Vonk 234-36; van Dijk and Kintsch 8). Situational models include psychological images cause-and-effect relationships, visual imagination, affect and the like (see Law 108). Kenneth Goodman suggests that reading is a guessing game, and therefore another critical feature of reading comprehension is constructing bridging inferences (such as cause-and-effect relationships) for identifying personalities of the characters, the theme, as well as the writing objectives (127; see also Graesser, Singer, Trabasso 386-88; van den Broek 548). In addition to bridging inferences, successful readers should be able to come up with connotations when reading about the fictional characters and their encounters. During the process, their emotional responses are recalled before transference takes place, which leads to an understanding of the situation and the characters' feelings. Through drama activities, different forms of imagination are elicited and students are enabled to transform the character images into mental images. Cognitive activities and emotions are hence organically integrated whereby reading comprehension is attained and the moral sense developed (see Ho 102; Meng 265-68).

Teaching procedures in this study were designed according to the suggested sequence of CSL learning. Listening and speaking activities were carried out to activate the students' verbal and mental lexicon. Hence, they were taught to form phrases with words, while learning the Chinese character components and structures for developing their literacy, character writing ability, and knowledge about phrases. After that, the teacher introduced students to the story genre with a 4-panel comic strip and provided them with further verbal input with an exercise requiring students to verbally tell their own life experiences. After the students had mastered the story genre, the teacher made use of a peer-written storybook Ying Mei's Grandmother as the course text. In this story, an EM protagonist has a conflict owing to cultural differences with her grandmother who recently arrived from India to Hong Kong. The discussions of the story and differentiated exercises, accessed and enriched the students' life experiences, mental lexicon, phrases, and sentences at the same time. Students explored various reading strategies including segmentation of sentences (locating phrases), locating keywords, predicting story plots and conclusions about the relationships between characters. The story genre was used to analyze the text structure. Drama pedagogy was implemented in the form of monologue to allow the students express their own feelings about the stories, and to guide them through their analyses of characters, their behavior and intentions, as well as through their analysis of theme. The objective of this part of the intervention was to enable students to understand the characters' situations and the texts alike in order to develop their listening and speaking abilities at the same time. Finally, the students were asked to write a story to sum up the language-related knowledge they acquired in the course. Also, a pre-test was carried out at the beginning of the term before the teaching experiment. Upon completion of the experiment, a post-test was carried out before the end of the term.

The listening assessment, conducted in Cantonese (the local lingua franca), was centered on the eating habits of secondary school students. The format was in the form of a conversation between four people. The 20-minute assessment was divided into two parts, each consisted of 6 multiple-choice questions. The listening tasks included summarizing the content of the conversations, identifying the coherence and relevance among different linguistic segments, and understanding basic information about the people and events within the conversation. The speaking assessment, a criterion-referenced test during which student performance is compared to a set of expected criteria, was divided into two parts, namely "Telling the Story" and "Group Conversation." The former assessed the students' ability to tell a complete story based on the given picture in 1 minute. The assessment criteria were the students' abilities to naturally, fluently, and accurately express themselves based on the picture and discern the implications. 
The second part, "Group Conversation," required the students to exchange views for 3 minutes on the topic "Allowing students to eat in class" in the form of a group discussion. The assessment criteria included the ability to produce a clear description of the theme, to successfully elaborate their viewpoints, and appropriately conclude the task. Students were also assessed on their ability to respond to various opinions. The third, the literacy assessment, was to evaluate the students' mental lexicon, that is, all lexical items relating to a certain stimulus. Students were asked to look at a picture featuring a scenario in school (including class times and activities on the playground) before writing down their mental lexicon consecutively for 5 minutes. It was accompanied by the reading assessment (also a criterion-referenced test) for which the students were asked to read 3 passages: 1) a short and simple practical writing (invitation card) with around 100 words 2) a longer piece of practical writing (personal letter) of around 200 words and 3) a narrative essay of around 300 words. The assessed items within the reading assessment included comprehension of learned vocabulary, understanding of paragraph-level meanings and relationships in simple narrative texts, general understanding of simple events in sequential or flashback forms, understanding of basic practical writing, and understanding of major information. Finally, in the writing assessment, students were to write one narrative essay on a typical school day with reference to a series of given pictures. No word limit was imposed and the assessment criteria included: content (in terms of richness), structure (appropriateness), vocabulary (variety), sentence structures (grammar), style (variations of words), the number of orthographic errors, and the use of punctuation.

Improvement was found in all of the five assessments (evidenced by mean increases ranging from 2.92 to 17.67) in the post-test. One particular area that the author would like to highlight is writing, which is, as mentioned earlier in this paper, the final stage of Chinese language learning. In the writing pre-test, the mean and standard deviation (SD) of the cohort were 5.14 and 6.09 respectively, implying that many students were unable to produce texts at the sentential level. Low-level students often managed to scribble only irrelevant, ungrammatical short phrases or sentences (see figure 12), which was reflected in the low mean and SD for content within the cohort ( 0.73 and 1.06 respectively). High-level students performed better than their low-level counterparts for they showed knowledge of paragraphing, time words and event sequence. However, orthographic, semantic, and grammatical errors were not uncommon, and coherence was a prevalent issue.

Upon completion of the one-year teaching experiment, the cohort performed generally well in the post-test (with an 11.40 increase to 16.54 for mean, SD=2.6), as most students were able to express themselves fluently in simple yet extended paragraphs. As for the lower-level students, they were able to use simple sentences for describing the event and produce short narrative writing on the happenings at school with reference to the different times of the day. For the high-level students, despite the fact that there were occasional errors, the sentences were basically correct in terms of grammar, semantics, and orthography. Certain high-level students were then able to apply the $4 \mathrm{~W}$ principle while showing correct use of time words like "first," "second," "in the afternoon," and "finally" as bridging words that enhanced coherence. Overall, students' abilities in listening, speaking, literacy, reading, and writing all showed improvement upon completion of the course, particularly in the speaking and reading section. The teaching strategies, adopted in accordance with the integrative approach featured earlier in the paper, were proven to be useful for CSL learning. A few core elements have been identified for the success of an EM CSL curriculum, namely authentic teaching materials, literacy education, teaching of reading, drama in education, and teaching of writing.

During the intervention, teaching materials including comic strips. Picture books were used as core texts which matched EM CSL learners' mental age, life experiences, and Chinese proficiency. Introducing compelling comprehensive input to the Chinese language subject through the peer-written story in various forms (i.e. reading practice, dramatic monologue, and writing practice), learning became meaningful to the students, which in turn enhanced their motivation. Besides, such materials allowed the teacher to design multilevel materials according to the concept of differentiation to cater to the diverse language proficiency levels and learning needs. Free voluntary reading was encouraged through the use of teaching materials upon initial attempts during the teaching experiment and students' speaking, listening, literacy, reading, and writing abilities were developed in a holistic manner. To confront the difficulty among adolescent EM CSL learners in understanding the stories' characters, the content of teaching materials was tailored to relate to the students' life experiences for easy access of their mental lexica. Also, the teacher referred to the sequence of learning Chinese as a second language and started from speaking and listening in her attempt to develop EM students' language skills. Combining variation theory and the integrative perceptual approach for teaching Chinese script, the proposed curriculum enhanced students' learning of characters and phrases while creating a space for learning. In addition, learning about the stories' characters through etymology enhanced students' recognition ability further.

In conclusion, picture story books represent an ideal means for introducing shared structures and features in stories and narrative writings to EM CSL learners. Once students are familiarized with the schema of the story genre through acquisition of reading strategies, their reading efficacy is improved, which in turn aids the development of their writing skills. Drama pedagogy capitalizes on students' opportunities to perceive the given contexts from the characters' perspectives, and to experience it through the construction of the situational model. Through monologues, students' perceive and perform emotions during the construction of the situational model and allow for the transference. Given that monologue emphasizes spontaneity and gradual advancement, the adolescent learners in the teaching experiment were able to "interact" with the texts while acquiring their own perspectives in a relatively relaxed learning environment. In addition, the integrated approach was able to motivate the adolescent learners to participate in classroom activities and consolidate their understanding of text implications. At the same time, their speaking skills were enhanced by enriching their mental lexica when receiving reading and writing training. Each reading tapped into the learners' different experiences through multisensory learning, which can lead to personal growth and an enhanced understanding of the world in the 
long run. Detailed analyses on the relationship between the sociolinguistic background and the performance of individual participants within the cohort are recommended as the next stage of this study to investigate the role of family literacy in the learning of CSL. I also suggests further research on the effectiveness of integrated approaches for the teaching and learning of CSL at the advanced level.

Note: I thank the Education Bureau of the Hong Kong Special Administrative Region for their project sponsorship and the school principal, teachers, and students who participated in my study. I also thank Loretta Tam for her editorial assistance and Vikki Tsui and Ka-wa Sun for their research assistance.

\section{Works Cited}

Arnett, Jeffrey. "Adolescents' Uses of Media for Self-Socialization." Journal of Youth and Adolescence 24.5 (1994): 519-33.

Bestgen, Yves, and Vincent Dupont. "The Construction of Spatial Situation Models During Reading." Psychological Research 67 (2003): 209-18.

Cheung, Wing Tak (張永德). "童書閱讀與教學 — 圖畫書" ("Children's Books and Teaching: Picture Storybooks"). Hong Kong: Hong Kong Education Bureau, 2012.

Cohen, Jacob. Statistical Power Analysis for the Behavioral Sciences. San Diego: Academic P, 1998.

Curriculum Development Council of Hong Kong (香港課程發展委員會). 基礎教育課程指引: 各盡所能·發揮所長 (Basic Education Curriculum Guide: Building on Strengths [Primary 1-Secondary 3]). Hong Kong: The Government of the Hong Kong Special Administrative Region, 2002.

Education Bureau of HKSAR (香港特別行政區政府教育局). "第四章 學習範疇及教學說明" ("Chapter 4 Key Learning Areas and Notes on Instruction"). 中國語文課程指引(Curriculum Guide for Chinese Language). Hong Kong: The Government of the Hong Kong Special Administrative Region, 2001.

Eggins, Suzanne. An Introduction to Systemic Functional Linguistics. London: Continuum, 2004.

Goodman, Kenneth. "Reading: A Psycholinguistic Guess Game." Journal of the Reading Specialist 5 (1976): 12635.

Graesser, Arthur, Murray Singer, and Tom Trabasso. "Constructing Inferences during Narrative Text Comprehension." Psychological Review 101.3 (1994): 371-95.

Halliday, Michael, and Christian Matthiessen. Introduction to Functional Grammar. London: Routledge, 2014.

Ho, Shun Yee (何洵怡). "以聲韻活出意象情韻 - 朗讀劇場在中國文學課的成效" ("Voicing Out Imageries and Emotions: The Effectiveness of Readers' Theater Experience in the Chinese Literature Classroom"). National Taiwan Normal University Bulletin 49.2 (2004): 101-22.

Hong Kong Curriculum Development Council. Chinese Language Education Key Learning Area: Supplementary Guide to the Chinese Language Curriculum for Non-Chinese Speaking Students (English Translated Version). Hong Kong: The Government of the Hong Kong Special Administrative Region, 2008.

Johnson-Laird, Philip. Mental Models. Cambridge: Cambridge UP, 1983.

Justice, Laura, and Joan Kaderavek. "Topic Controlling During Shared Storybook Reading: Mothers and Their Children with Language Impairments." Topics in Early Childhood Special Education 23.3 (2003): 137-50.

Kaur, Kulwinder, and Kiram Gobindram. 英美的㭁㭁 (Ying Mei's Grandmother). Hong Kong: The University of Hong Kong, 2010.

Ki, Wing 'Wah (永永華), and Ada Poon (潘溫文), eds. 閱讀及創作之旅: 非華語學生與中文圖畫書 (Journey of Reading and Creation: Ethnic Minority Students and Picture Books). Hong Kong: The University of Hong Kong, 2011.

Krashen, Stephen. Free Voluntary Reading. Westport: Libraries Unlimited, 2011.

Krashen, Stephen. The Power of Reading: Insights from the Research. Portsmouth: Heinemann, 2004.

Kwan, Che-ying (關之英). "中文作為第二語言: 教學誤區與對應教學策略之探究" ("Chinese as a Second'Language: A Study on the Problems with Teaching and the Relevant Teaching Strategies"). 中國語文通訊 (Newsletter of Chinese Language) 91.2 (2012): 61-82.

Lam, Carrie. Initiatives Aim to Aid Minorities' Integration. Hong Kong: The Government of Hong Kong Special Administrative Region, 2014.

Law, Doris (羅燕琴). "篇章推理與中文語文能力的關係" (The Relationship between Discourse Inference and Chinese Language Proficiency: An Analysis on the Individual Difference in Chinese Reading Comprehension Among Primary School Students"). 課程論壇 (Curriculum Forum) 6.2 (1997): 106-17.

Lee, Yu-mei (李玉玫). 創意戲劇化圖畫書教學 (Creative Drama Pedagogy and Picture Storybooks). Taipei: Showwe, 2012.

Leong, Che Kan, Shek Kam Tse, Elizabeth Loh, and Wing Wah Ki. "Orthographic Knowledge Important in Comprehending Elementary Chinese Text by Users of Alphasyllabaries." Reading Psychology 32.3 (2011): $237-71$.

Leung, Constant, Roxy Harris, and Ben Rampton. "The Idealized Native Speaker, Reified Ethnicities, and Classroom Realities. TESOL Quarterly 31.3 (1997): 543-60.

Loh, Elizabeth, and Shek Kam Tse. "An Investigation of School-based Curriculum of Effective Chinese Character Learning for Non-Chinese Speaking Kindergarteners." Journal of Korean Classical Chinese Education 28 (2012): $171-95$.

Malu, Kathleen. "Exploring Children's Picture Storybooks with Adult and Adolescent EFL Learners." English Teaching Forum 3(2013): 10-18.

Marton, Ference, and Shirley Booth. Learning and Awareness. Mahwah: Lawrence Erlbaum, 1997.

Meng, Zhaolan (孟昭蘭). 情緒心理學 (Psychology of Emotions). Beijing: Peking UP, 2005.

Noordman, Leo, and Wietske Vonk. "Discourse Comprehension." Language Comprehension: A Biological Perspective. Ed. Angela Friederici. Berlin: Springer, 1998. 229-62.

Pine, Nancy, and Zhenyou Yu. "Early Literacy Éducation in China: A Historical Overview." Perspectives on Teaching and Learning Chinese Literacy in China. Ed. Cynthia Leung and Jiening Ruan. Berlin: Springer, 2012. 81-106.

Purcell-Gates, Victoria, Susan L'Allier, and Dorothy Smith. "Literacy at the Harts' and the Larsons': Diversity among Poor, Innercity Families." The Reading Teacher 48.7 (1995): 572-79.

Shum, Mark (岑紹基), Linda Tsung (叢鐵華), and Wing Wah Ki (祁永華). "香港語言政策與少數族裔人士的語言教育" ("Language Policy in Hong Kong and Language Education for Ethnic Minorities"). 香港語言生活綠皮書: 中國語言生活狀況報 告 (上篇) (Green Paper on Language and Life in China: A Report on China's Current Situation in Language and Life). Ed. Research Group for China's Current Situation in Language and Life. Beijing: The Commercial P, 2007. Vol. 1, 281-93.

Tomlinson, Carol. How to Differentiate Instruction in Mixed-ability Classrooms. Alexandria: Association for Supervision and Curriculum Development, 2001. 
Elizabeth K.Y. Lo, "Picture Storybooks in Teaching Chinese as a Second Language"

page 7 of 7

CLCWeb: Comparative Literature and Culture 18.2 (2016): <http://docs.lib.purdue.edu/clcweb/vol18/iss2/12>

Thematic Issue New Work in the Empirical Study of Literature. Ed. Aldo Nemesio

The, She Kan. "第二語言中文教學:多層教材與教法理論" ("Teaching Chinese as a Second Language: A Theory of Differentiated Teaching Materials and Pedagogy"). 非華語學生的中文學與教: 課程、教材、教法與評在 (Devising a Chinese-Language Curriculum for Non-Chinese-Speaking Students in Hong Kong). Ed. She k Mam Sse (謝錫金), Wing Wa Ki (柿永華), and Mark Shim (岑紹基). Hong Kong: Hong Kong UP, 2012. 15-35.

The, She Kame, ed. 高效脵字教與學 (Effective Teaching and the Learning of Chinese Characters). Hong Kong: Green-

The, She Mam, and Chum Lung Li. "個案九: 識字教學" ("Case Number 9: Teaching Chinese Characters"). 非華語學生 in Hong Kong). Ed. Sher Kan Ts (謝錫金) a Chinese-language Curriculum for Non-Chinese-Speaking Students Kong UP, 2012. 207-18.

The, She Ram, and Elizabeth Lo. 中國語文校內評估工具(非華語學生適用 (Chinese Language Assessment Tool for Non-Chinese Speaking Students). Hong Kong: Curriculum Development Institute, Education Bureau of Hong Kong Special Administrative Region, 2011.

The, She Ram, and Elizabeth Lo, eds. 怎樣教非華語幼兒有效學習中文 (Effective Teaching and Learning of Chinese

The, She Kat, Ference Marten, Wing Wa Ki, and Elizatudents). Beijing: Beijing Normal UP, 2014.

'Chinese Characters" Instructional Science 35.5 (2007): 375-406.

Van den Brock, Paul. "Comprehension and Memory of Narrative Texts: Inferences and Coherence." Handbook of Psycholinguistics. Ed. Morton Ann Gernsbacher. San Diego: Academic P, 1994. 539-88. Van Dijk, Thun, and Walter Kintsch. Strategies of Discourse Comprehension. New York: Academic P, 1983.

Author's profile: Elizabeth K.Y. Lo teaches Chinese-language education at the University of Hong Kong. Her interest in scholarship include the teaching and learning of Chinese as a second language. Lon's recent publications include "Patterns in PIRLS Performance," Asian Journal of Education and e-Learning (2015, with Stephen D. Krashen) and "Effective Teaching and Learning of Chinese Characters for Non-Chinese Speaking Kindergarten Students," Beijing Normal University Press (2014, with She Kan Toe). E-mail: <mailto:ekyloh@hku.hk> 